\title{
PERSONAL PROFILE
}

\section{Cheng Yuqi: President of Geological Society of China}

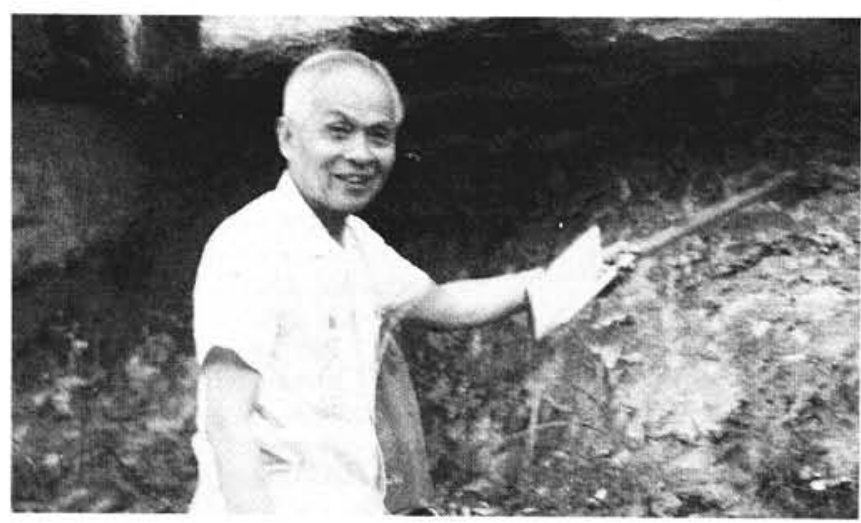

To many workers on the granitoid rocks of the Caledonides, the name Y.C. Cheng probably calls to mind the classic 1944 paper on the migmatites of Sutherland in Scotland, a result of a doctoral study at the University of Liverpool. While myself a graduate student at Liverpool some 25 years ago, 1 came across a carefully wrapped collection of specimens stored in the basement of the Geology Department in a tea chest with the name $\mathrm{Yu}$-Chi Cheng on the side. I often wondered what had become of him after his return in 1938 to China. Had he been able to use his skills on Chinese metamorphics and plutonics? Had he survived the tumultous transition to the New China and the many upheavals later? The answer to both questions is a resounding "Yes, indeed," for Prof. Cheng Yuqi, to use his modern name, is one of China's most senior geoseientists with a long and illustrious career as geologist, civil servant and scientific leader.

Born in 1912 , the young Cheng was drawn to geography by discussions with his father about the land and landforms described in such historical novels as "The Three Kingdoms" and "Tales of the States of the East Chou Dynasty," both written more than two millenia ago. At the age of 17 , he began university studies in geography at what is now Qinghua University in Beijing, where he soon switched to geology, encouraged by Prof. Xie Jiangong.

Following graduation in 1933, and a brief stint with the Geological Survey of China he won a scholarship to England. Here he followed the advice of Professor J.S. Lee (later, as Lee Siguang, Minister of Geology from 1952-1969), who had just heard Professor H.H. Read deliver in London his classic paper on polymetamorphism in Unst, to seek a place with Read at Liverpool. The Department was then tiny, with about 10 undergraduate and two postgraduate students, so that staff-student relations were close and Cheng felt "quite at home."

In $1938 \mathrm{Dr}$. Cheng returned to China where he became Head of the laboratories of Mineralogy and Petrology as well as of Economic Geology within the Geological Survey of China. Appointed Senior Research Fellow in the Institute of Geology of Academica Sinica in 1946, he rose rapidly in government service after the founding of the People's Republic in 1949, becoming at various times Director of the Institute, Chief Geologist, and Deputy Minister of the Ministry of Geology and Mineral Resources.
Prof. Cheng even today has a very full "portfolio," which includes Deputy Director of the Earth Science Division of the Academica Sinica Scientific Council, Professor of the Postgraduate School of the Chinese Academy of Geological Sciences, President of the Geological Society of China and Vice-President of the Society of Mineralogy, Petrology and Geochemistry of China.

Naturally, Prof. Cheng has seen tremendous changes in the development of geological ideas on China and in the growth of its scientific community. When he graduated in 1933 there were about 80 geologists employed in China, rising to a little over 300 by 1949 and to a staggering total of nearly 100,000 today. This growth has been mirrored by an increase in membership of the Geological Society of China (founded in 1922 with 26 members) to 280 in 1933 (including many non-geologists and foreigners) to nearly 600 in 1949 and over 62,000 in 1988 . Prof. Cheng points with some pride to the increase in $1: 200,000$ geological map coverage from 0.18 of China's total landmass in 1933 to 678 today.

As Chairman or Co-chairman of China's National Committees for IGCP and ICL, Prof. Cheng is heavily involved in the growing number of international exchanges and cooperative projects in geology, with 23 IGCP project meetings held in China this year alone. And the Geological Society of China is also the national member for IUGS. Despite the difficulty of measuring the degree to which China has benefited by these activities, Prof. Cheng points to the fact that Chinese scientists are much more alert now than formerly to current developments and concepts, even though language is still a major obstacle. Despite the publication in China of about 80 geological journals at least with English abstracts, many by the Geological Society, few are known outside the country.

In addition to his administrative responsibilities, Prof. Cheng has found time to publish about 100 scientific papers, reports and books, including 39 wholly or partly in English. He has made many contributions to the study of iron deposits, including an influential classification of genetic types, and he has also worked on the Archaean and Early Proterozoic of China and its isotope chronology. However, his major contribution to basic geology has been on migmatites, the Chinese term for which "hun-he-yan" he introduced into Chinese geology in 1937, the year in which he visited classic Finnish locations under the guidance of P. Eskola and E. Mikola. Indeed in 1965 he proposed a "migmatitic series," subdivided on the basis of megascopic and microscopic features as well as of geological setting. His current ideas, based in part on recent theses by several of his graduate students, are summarized in his 1986 book, with Yang Zunyi and Wang Hongzhan "The Geology of China" published by Oxford.

There is no doubt that Prof. Cheng Yuqi has successfully bridged the gap between research and administration and between China and the scientific community outside. In July 1988, he returned to the University of Liverpool to receive an Honorary D.Sc., a tribute to his leadership nationally and internationally.

- A.R. Berger 

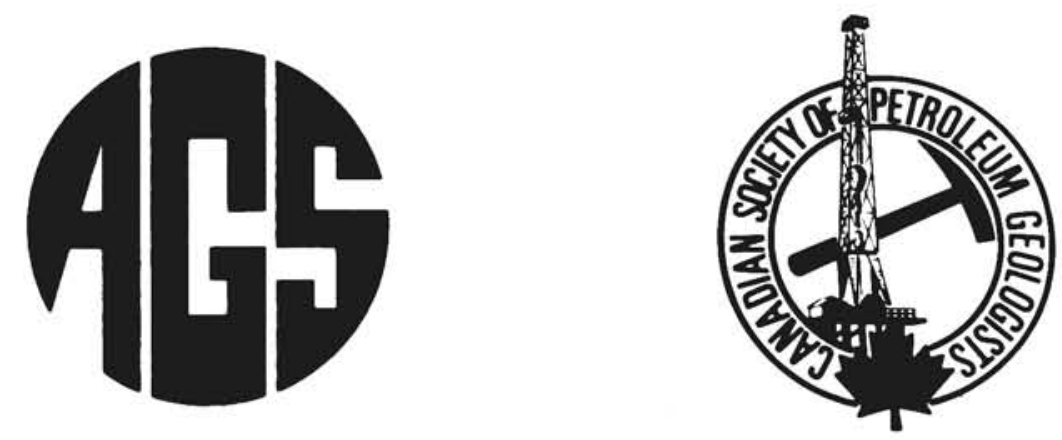

\title{
Sedimentary Basins \\ and
}

\section{Basin-Forming Mechanisms}

\author{
Edited by Christopher Beaumont and Anthony J. Tankard
}

CSPG Memoir 12

The publication's five sections are:

Extensional Basins

Models of Extensional Basins

Transtensional and Transpressive Basins

Foreland Basins

Intracratonic Basins

Hard cover 527 pages, 1987

$22 \times 28 \mathrm{~cm}$.

Cost including postage and handling:

Canada - $\$ 88.00$

International - $\$ 92.00$
AGS Special Publication 5

This publication is the proceedings of the "Basins of Eastern Canada and Worldwide Analogues" symposium held in Halifax, Canada in August 1986 co-sponsored by the Atlantic Geoscience Society, Canadian Society of Petroleum Geologists and Inter-Union Commission on the Lithosphere Working Group 3.

It contains 34 papers encompassing many aspects of the tectonic development of basins in North America, Europe and Asia.

Send order to: Canadian Society of Petroleum Geologists \#505, 206 - 7th Avenue S.W. Calgary, Alberta, Canada T2P OW7

Please send money in Canadian funds or equivalent with order, or supply Visa Card number and expiry date. 